\title{
ANALISIS LAPORAN KEUANGAN BERDASARKAN TINGKAT PROFITABILITAS PADA PT. BANK PERKREDITAN RAKYAT LPN TARANTANG KABUPATEN DHARMASRAYA
}

\author{
Yana Putri, Afriyeni \\ Akademi Keuangan dan Perbankan Padang \\ Afriyeni.yen@gmail.com
}

\begin{abstract}
This study aims to determine advantage of Profitability in the Bank Credit People of LPN Tarantang Sub-Province of Dharmasraya period 2013-2016. The object of research is to analyze Financial Statements Balance Sheet at the Bank Credit People of LPN Tarantang. This research is a descriptive study with the data used are the financial statements. Analysis using liquidity ratios used to Return on Assets, Return on Equity, Operating Expenses, and Net Profit Margin. The results showed that the level of Profitability bank seen from Return on Assets on Bank Credit People of LPN Tarantang Sub-Province Dharmasraya in years 2013 period amounted to $2,43 \% \%$, in years 2014 amounted to $08,60 \% \%$, in years 2015 amounted to $3,10 \%$, and $1,69 \%$ in years 2016 , these results are included in the category of less healthy. Return on Equity in 2013 amounted to 17,18\%, in years 2014 amounted to 5,48\%, in years 2015 amounted to 17,86\%, and in years 2016 amounted to11,13\%, these result are included in the category of slimmer goodness. Operating Expenses in years 2013 amounted to 88,04\%, in years 2014 amounted to 96,27\%, in years 2015 amounted to $116 \%$, and amounted $111 \%$ in years 2016, these result are included in the category not efficiency. Net Profit Margin in years 2013 amounted to 12,09\%, in years 2014 amounted to 03,94\%, in years 2015 amounted to 16,28\%, and 10,04\% in years 2016. These result are included in the category good.
\end{abstract}

Keywords : Financial Statement, of Profitability

\section{LATAR BELAKANG}

Dalam era globalisasi sekarang ini peranan bank sangat penting bagi Masyarakat Indonesia, karena pada dasarnya perbankan bertujuan untuk menunjang pembangunan nasional dalam meningkatkan taraf hidup masyarakat.

Menurut Undang-undang RI Nomor 10 Tahun 1998 Bank adalah badan usaha yang menghimpun dana dari masyarakat dalam bentuk simpanan dan menyalurkannya kepada masyarakat dalam bentuk kredit atau bentuk-bentuk lainnya dalam rangka meningkatkan taraf hidup rakyat banyak. 
Dalam Undang-undang Nomor 10 Tahun 1998 tentang perbankan, Bank Perkreditan Rakyat adalah bank yang melaksanakan kegiatan usaha secara konvensional atau berdasarkan prinsip syariah yang dalam kegiatannya tidak memeberikan jasa dalam lalu lintas pembayaran.

Laporan keuangan merupakan data-data yang sifatnya kuantitatif. Menurut Harahap (2000:105) dimana laporan keuangan menggambarkan kondisi keuangan suatu perusahaan dalam jangka waktu tertentu.

Menurut Munawir (2007:240), Profitabilitas adalah rasio yang digunakan untuk menilai kemampuan perusahaan untuk memperoleh keuntungan. Berdasarkan pernyataan tersebut profitabilitas suatu bank dapat diukur dengan beberapa ratio-ratio keuangan yaitu Return on Assets (ROA), Return on Equity (ROE), Biaya Operasional (BOPO), Net Profit Margin (NPM)

\section{Tabel 1}

Perkembangan Rasio Profitabilitas PT. BPR LPN Tarantang Kabupaten Dharmasraya Periode 2013-2016

\begin{tabular}{|l|c|c|c|c|}
\hline \multicolumn{1}{|c|}{ Keterangan } & $\mathbf{2 0 1 3}$ & $\mathbf{2 0 1 4}$ & $\mathbf{2 0 1 5}$ & $\mathbf{2 0 1 6}$ \\
\hline Return on Assets & $2,43 \%$ & $08,60 \%$ & $3,10 \%$ & $1,69 \%$ \\
\hline Return on Equity & $17,18 \%$ & $5,48 \%$ & $17,86 \%$ & $11,13 \%$ \\
\hline BOPO & $88,04 \%$ & $96,27 \%$ & $116 \%$ & $111 \%$ \\
\hline Net Profit Margin & $12,09 \%$ & $03,94 \%$ & $16,12 \%$ & $10,04 \%$ \\
\hline
\end{tabular}

Sumber : Data Olahan

Berdasarkan tabel diatas dilihat bahwa PT. BPR LPN Tarantang dalam hal ini neraca dan laporan laba rugi perusahaannya dalam posisi profitabilitas masih berfluktuasi. Hal ini dapat dilihat pada tahun 2013 ROA $(2,43 \%)$ sedangkan tahun 2014 ROA $(08,60 \%)$ mengalami penurunan sebesar 6,17\%. Tahun $2013 \mathrm{ROE}$ $(17,18 \%)$ sedangkan tahun 2014 ROE $(5,48 \%)$ mengalami penurunan sebesar $11,7 \%$. Tahun 2013 BOPO $(88,04 \%)$ sedangkan tahun 2014 mengalami kenaikkan sebesar 8,23\% dan tahun 2013 NPM (12,09\%) sedangkan tahun 2014 (03,94\%) mengalami penurunan sebesar $8,15 \%$.

Rumusan Masalah

Adapun rumusan masalah dalam penulisan tugas akhir ini yaitu bagaimana tingkat profitabilitas yang diukur dengan rasio ROA, ROE, BOPO, dan NPM pada PT. BPR LPN Tarantang Kabupaten Dharmasraya periode 2013-2016.

\section{TINJAUAN PUSTAKA}

\section{Bank dan Jenis-jenisnya}

Menurut Undang-undang No. 10 Tahun 1998 bank adalah badan usaha yang menghimpun dana dari masyarakat dalam bentuk kredit dan atau bentuk-bentuk lainnya dalam rangka meningkatkan taraf hidup rakyat banyak.

Menurut Undang-undang Perbankan No. 10 Tahun 1998 bank terdiri atas dua jenis, yaitu : 
1. Bank umum adalah bank yang melaksanakan kegiatan usaha secara konvensional dan atau berdasarkan prinsip syariah yang dalam kegiatannya memberikan jasa dalam lalu lintas pembayaran.

2. Bank Perkreditan Rakyat adalah bank yang melaksanakan kegiatan usaha secara konvensional atau berdasarkan prinsip syariah yang dalam kegiatannya tidak memberikan jasa dalam lalu lintas pembayaran.

\section{Laporan keuangan}

Menurut Harahap (2009;7) laporan keuangan adalah merupakan hasil akhir dari suatu proses akuntansi yang menjadi bahan informasi bagi para pemakainya sebagai salah satu bahan dalam proses pengambil keputusan.

Menurut Harahap (1997:190), Analisis laporan keuangan adalah menguraikan pos-pos laporan keuangan menjadi unit informasi yang lebih kecil dan melihat hubungannya yang bersifat signifikan baik antara data kuantitatif maupun data non- kuantitatif.

\section{Bentuk-bentuk Laporan Keuangan}

Laporan keuangan yang disajikan setiap akhir periode tersebut didasarkan pada Standar Akuntansi Keuangan (SAK) yang terdiri atas :

a. Neraca (Balance Sheet) adalah laporan keuangan yang menunjukkan keadaan keuangan pada akhir periode terdiri aktiva, kewajiban dan modal.

b. Laporan Laba/Rugi adalah laporan yang menunjukkan pendapatan dan beban dari suatu perusahaan dalam suatu periode.

c. Laporan Perubahan Modal adalah laporan yang menunjukkan adanya perubahan modal.

d. Laporan Arus Kas (Cash Flows)adalah laporan yang menunjukkan arus masuk dan arus keluar kas.

\section{Profitabilitas}

Profitabilitas adalah rasio yang digunakan untuk menilai kemampuan perusahaan untuk memperoleh keuntungan (Munawir, 2007:240).

Rasio profitabilitas merupakan rasio untuk menilai kemampuan perusahaan dalam mencari keuntungan. Rasio ini juga memberikan ukuran tingkat efektivitas manajemen suatu perusahaan (Kasmir, 2008:196).

\section{Tujuan dan Manfaat Rasio Profitabilitas}

Kasmir (2008:197), menerangkan bahwa tujuan dan manfaat rasio profitabilitas:

a. Untuk mengukur laba yang diperoleh perusahaan dalam suatu periode serta perkembangan laba perusahaan dari waktu ke waktu dan menilai besarnya laba bersih setelah pajak terhadap modal sendiri.

b. Mengukur produktivitas dari seluruh dana perusahaan yang digunakan baik modal sendiri maupun pinjaman.

\section{Faktor- faktor yang Mempengaruhi Profitabilitas}

Manajemen adalah faktor utama yang mempengaruhi profitabilitas bank, manajemen yang baik ditunjang oleh faktor modal dan kombinasi ideal untuk keberhasilan bank.

Dari segi manajemen paling sedikit ada tiga aspek yang paling diperhatikan, yaitu Balance sheet management meliputi assets dan liability management, artinya pengaturan harta dan hutang secara bersama. Operating management 
merupakan manajemen bank yang berperan dalam menaikkan profitabilitas dengan cara menekan biaya.

\section{METODE PENELITIAN}

Dalam pengumpulan data dan bahan untuk penelitian ini digunakan metode penelitian sebagai berikut :

\section{Metode Pengumpulan Data}

a. Study Lapangan (Field Research)

Peninjauan langsung ke objek yang dipilih untuk meneliti hasil data sekunder. Penelitian langsung ke lapangan ini akan dapat membantu Penulis untuk melengkapi data yang diperlukan.

b. Study Kepustakaan(Library Research)

Penelitian yang dilakukan keperpustakaan beberapa buku-buku ilmiah dan tulisan-tulisan yang berhubungan dengan pembahasan yang dilakukan.

\section{Metode Analisa Data}

Dalam menganalisa data, menggunakan analisa data kualitatif dan kuantitatif. Dimana metode kualitatif menggambarkan, memahami dan menjelaskan data yang diteliti selama penelitian berlangsung, sedangkan metode kuantitatif menganalisa perhitungan tingkat profitabilitas pada PT. BPR LPN Tarantang Kabupaten Dharmasraya.

\section{HASIL DAN PEMBAHASAN}

a. Return on Assets (ROA)

Menunjukkan kemampuan suatu perusahaan menghasilkan laba dari aktiva yang dipergunakan. Berdasarkan data yang diperoleh Return on Assets BPR LPN Tarantang dari tahun 2013 sampai dengan tahun 2016 ditunjukkan pada tabel di bawah ini.

\section{Tabel 2}

Perhitungan Return on Assets BPR LPN Tarantang Kabupaten Dharmasraya Tahun 2013-2016

(Dalam Ribuan Rupiah)

\begin{tabular}{|l|c|c|c|c|}
\hline \multicolumn{1}{|c|}{ Komponen } & $\mathbf{2 0 1 3}$ & $\mathbf{2 0 1 4}$ & $\mathbf{2 0 1 5}$ & $\mathbf{2 0 1 6}$ \\
\hline $\begin{array}{l}\text { Laba bersih } \\
\text { sebelum pajak }\end{array}$ & 694.393 & 221.488 & 714.753 & 445.285 \\
\hline Total Aktiva & 28.552 .736 & 25.769 .320 & 23.046 .203 & 26.359 .367 \\
\hline Return On Assets & $2,43 \%$ & $08,60 \%$ & $3,10 \%$ & $1,69 \%$ \\
\hline
\end{tabular}

Sumber : Data Olahan

Dengan Formula :

$$
\mathrm{ROA}=\frac{\text { Laba sebelum pajak }}{\text { Total Aktiva }} 100 \%
$$

1. Tahun 2013

$\mathrm{ROA}=\frac{R p \cdot 694 \cdot 393}{R p \cdot 28 \cdot 552.736} \times 100=2,43 \%$ 
Artinya kemampuan BPR LPN Tarantang dalam menghasilkan laba terhadap penggunaan sejumlah aktiva perusahaan dengan nilai ROA sebesar 2,43\% dengan arti bahwa setiap Rp. 100 aktiva yang dimilikinya, bank mampu menghasilkan laba bersih sebelum pajak sebesar Rp. 2,43. Menurut standar BI bank yang sehat adalah bank yang memiliki ROA lebih dari $1,5 \%$, sementara BPR LPN Tarantang mampu menghasilkan ROA sebesar 2,43\% melebihi dari standar yang telah ditentukan.

2. Tahun 2014

$\mathrm{ROA}=\frac{R p \cdot 221.488}{R p \cdot 25.769 \cdot 320} \times 100=08,60 \%$

Artinya kemampuan BPR LPN Tarantang dalam menghasilkan laba terhadap penggunaan sejumlah aktiva perusahaan dengan nilai ROA sebesar 08,60\% dengan arti bahwa setiap Rp. 100 aktiva yang dimilikinya, bank mampu menghasilkan laba bersih sebelum pajak sebesar Rp. 08,60. Menurut standar BI bank yang sehat adalah bank yang memiliki ROA lebih dari 1,5\%, sementara BPR LPN Tarantang mampu menghasilkan ROA sebesar 08,60\% di bawah standar yang telah ditentukan.

3. Tahun 2015

$\mathrm{ROA}=\frac{R p \cdot 714 \cdot 753}{R p \cdot 23 \cdot 046 \cdot 203} \times 100=3,10 \%$

Artinya kemampuan BPR LPN Tarantang dalam menghasilkan laba terhadap penggunaan sejumlah aktiva dengan nilai ROA sebesar 3,10\% dengan arti bahwa setiap Rp. 100 aktiva yang dimilikinya, bank mampu menghasilkan laba bersih sebelum pajak sebesar Rp. 3,10. Menurut standar BI bank yang sehat adalah bank yang memiliki ROA lebih dari 1,5\%, sementara BPR LPN Tarantang mampu menghasilkan ROA sebesar 3,10\% melebihi dari standar yang telah ditentukan.

4. Tahun 2016

$\mathrm{ROA}=\frac{R p \cdot 445 \cdot 285}{R p \cdot 26 \cdot 359 \cdot 367} \times 100=1,69 \%$

Artinya kemampuan BPR LPN Tarantang dalam menghasilkan laba terhadap penggunaan sejumlah aktiva perusahaan dengan nilai ROA sebesar 1,69\% dengan arti bahwa setiap Rp. 100 aktiva yang dimilikinya, bank mampu menghasilkan laba bersih sebelum pajak Rp.1,69. Menurut standar BI bank yang sehat adalah bank yang memiliki ROA lebih dari 1,5\%, sementara BPR LPN Tarantang mampu menghasilkan ROA sebesar 1,69\% melebihi dari standar yang telah ditentukan.

b. Return on Equity (ROE)

Return on Equity menunjukkan dari modal sendiri untuk menghasilkan keuntungan bagi pemegang saham. Menurut standar BI ROE lebih dari 12\% dapat dikatakan baik. Berdasarkan data yang diperoleh ROE BPR LPN Tarantang dari tahun 2013 sampai dengan tahun 2016 ditunjukkan pada tabel di bawah ini. 
Tabel 3

Perhitungan Return on Equity BPR LPN Tarantang Kabupaten

Dharmasraya Tahun 2013-2016

(Dalam Ribuan Rupiah)

\begin{tabular}{|l|c|c|c|c|}
\hline \multicolumn{1}{|c|}{ Komponen } & $\mathbf{2 0 1 3}$ & $\mathbf{2 0 1 4}$ & $\mathbf{2 0 1 5}$ & $\mathbf{2 0 1 6}$ \\
\hline $\begin{array}{l}\text { Laba bersih setelah } \\
\text { pajak }\end{array}$ & 687.449 & 219.273 & 714.753 & 445.285 \\
\hline Modal Sendiri & 4.0000 .000 & 4.000 .000 & 4.000 .000 & 4.000 .000 \\
\hline Return on Equity & $17,18 \%$ & $5,48 \%$ & $17,86 \%$ & $11,13 \%$ \\
\hline
\end{tabular}

Sumber : Data Olahan

Dengan Formula :

$$
\mathrm{ROE}=\frac{\text { Laba bersih setelah pajak }}{\text { Modal Sendiri }} \times 100 \%
$$

1. Tahun 2013

$$
\mathrm{ROE}=\frac{R p \cdot 687.449}{R p \cdot 4.000 .000} \times 100=17,18 \%
$$

Artinya kemampuan BPR LPN Tarantang dalam memperoleh keuntungan dari modal sendiri adalah sebesar $17,18 \%$ artinya bahwa setiap Rp. 1 modal sendiri mampu menghasilkan Rp. 0,17 laba bersih setelah pajak. Menurut standar BI ROE yang baik adalah lebih dari 12\%, sementara BPR LPN Tarantang mampu menghasilkan ROE sebesar $17,18 \%$ melebihi dari standar yang telah ditentukan.

2. Tahun 2014

$$
\mathrm{ROE}=\frac{R P .219 \cdot 273}{R p \cdot 4.000 \cdot 000} \times 100 \%=5,48 \%
$$

Artinya kemampuan BPR LPN Tarantang dalam memperoleh keuntungan dari modal sendiri adalah sebesar 5,48\% artinya bahwa setiap Rp. 1 modal sendiri mampu menghasilkan Rp. 0,05 laba bersih setelah pajak. Menurut standar BI ROE yang baik adalah lebih dari $12 \%$, sementara BPR LPN Tarantang mampu menghasilkan ROE hanya sebesar 5,48\% di bawah standar yang telah ditentukan, karena kecilnya kemampuan bank dalam menghasilkan Return on Equity.

\section{Tahun 2015}

$$
\mathrm{ROE}=\frac{R p \cdot 714.753}{R p \cdot 4 \cdot 000 \cdot 000} \times 100=17,86 \%
$$

Artinya kemampuan BPR LPN Tarantang dalam memperoleh keuntungan dari modal sendiri adalah sebesar $17,86 \%$ artinya bahwa setiap Rp. 1 modal sendiri mampu menghasilkan Rp. 0,17 laba bersih setelah pajak. Menurut standar BI ROE yang baik adalah lebih dari $12 \%$, sementara BPR LPN Tarantang mampu menghasilkan ROE sebesar 17,86\% melebihi dari standar yang telah ditentukan. 
4. Tahun 2016

$\mathrm{ROE}=\frac{R p \cdot 445.285}{R p \cdot 4 \cdot 000.000} \times 100 \%=11,13 \%$

Artinya kemampuan BPR LPN Tarantang dalam memperoleh keuntungan dari modal sendiri adalah sebesar $11,13 \%$ artinya bahwa setiap Rp. 1 modal sendiri mampu menghasilkan Rp. 0,11 laba bersih setelah pajak. Menurut standar BI ROE yang baik adalah lebih dari $12 \%$, sementara BPR LPN Tarantang mampu menghasilkan ROE sebesar $11,13 \%$ di bawah standar yang telah ditentukan.

c. Biaya Operasional Terhadap Pendapatan Operasional (BOPO)

Rasio BOPO digunakan untuk mengukur perbandingan antara biaya operasional bank pendapatan. Menurut standar BI menetapkan rasio BOPO adalah dibawah 90\%. Berdasarkan data yang diperoleh BOPO BPR LPN Tarantang dari tahun 2013 sampai dengan tahun 2016 dapat ditunjukkan pada tabel di bawah ini.

\section{Tabel 4}

Perhitungan Biaya Operasional terhadap Pendapatan Operasional BPR LPN Tarantang Kabupaten Dharmasraya Tahun 2013-2016 (Dalam Ribuan Rupiah)

\begin{tabular}{|l|r|r|c|c|}
\hline \multicolumn{1}{|c|}{ Komponen } & $\mathbf{2 0 1 3}$ & $\mathbf{2 0 1 4}$ & $\mathbf{2 0 1 5}$ & $\mathbf{2 0 1 6}$ \\
\hline a.Beban Operasional & & & & \\
\hline -Beban Bunga & 1.689 .996 & 1.598 .654 & 1.403 .729 & 1.228 .193 \\
\hline -Beban Adm \& Umum & 2.815 .995 & 2.906 .115 & 2.822 .177 & 2.707 .249 \\
\hline -Beban Pemasaran & 134.918 & 77.182 & 85.051 & 64.695 \\
\hline -Peny. Aktiva Produktif & 140.988 & 588.617 & 728.258 & 842.592 \\
\hline $\begin{array}{l}\text {-Beban Operasional } \\
\text { lainnya }\end{array}$ & 223.125 & 182.930 & 95.718 & 78.822 \\
\hline Jumlah beban operasional & 5.005 .022 & 5.356 .498 & 5.134 .933 & 4.921 .551 \\
\hline b.Pendapatan Operasional & & & & \\
\hline -Bunga & 5.069 .016 & 4.921 .367 & 4.081 .907 & 3.243 .896 \\
\hline -Provisi & 306.938 & 370.192 & 89.026 & 172.546 \\
\hline -Lainnya & 308.614 & 272.102 & 218.138 & 1.015 .176 \\
\hline Jumlah pend. operasional & 5.684 .568 & 5.563 .661 & 4.389 .071 & 4.431 .618 \\
\hline BOPO & $88,04 \%$ & $96,27 \%$ & $116 \%$ & $111 \%$ \\
\hline
\end{tabular}

Sumber : Data Olahan

Dengan Formula :

$$
\mathrm{BOPO}=\frac{R p .5 .005 .022}{R p .5 .684 .568} \times 100 \%=88,04 \%
$$

$$
\text { BOPO } \frac{\text { Total Beban Operasional }}{\text { Total Pendapatan Operasional }} \times 100 \%
$$

1. Tahun 2013

Artinya, menurut standar Bank Indonesia BOPO di bawah 90\% bank dapat dikatakan efisien dalam menjalankan kegiatan operasionalnya, sementara kemampuan BPR LPN Tarantang dalam melakukan kegiatan operasionalnya dengan nilai BOPO sebesar 88,04\% dibawah standar yang telah ditentukan. Semakin rendah BOPO semakin efisien bank tersebut dalam mengendalikan biaya 
operasionalnya, dengan adanya efisiensi biaya, maka keuntungan yang diperoleh bank akan semakin besar

2. Tahun 2014

$\mathrm{BOPO}=\frac{\mathrm{RP} \cdot 5 \cdot 356.498}{\mathrm{Rp} \cdot 5 \cdot 563.661} \times 100 \%=96,27 \%$

Artinya, menurut standar BI BOPO di bawah $90 \%$ bank dapat dikatakan efisien dalam menjalankan kegiatan operasionalnya, sementara kemampuan BPR LPN Tarantang dalam melakukan kegiatan operasionalnya dengan nilai BOPO sebesar 96,27\% diatas standar yang telah ditentukan. Semakin tinggi BOPO semakin tidak efisien bank dalam mengendalikan biaya operasionalnya, dengan tidak efisiensinya biaya maka keuntungan yang diperoleh bank akan semakin kecil.

3. Tahun 2015

BOPO $=\frac{R p \cdot 5 \cdot 134.933}{R p \cdot 4.389 .071} x 100=116 \%$

Artinya, menurut Bank Indonesia BOPO di bawah 90\% bank dapat dikatakan efisien dalam menjalankan kegiatan operasionalnya, sementara kemampuan BPR LPN Tarantang dalam melakukan kegiatan operasionalnya dengan nilai BOPO sebesar $116 \%$ diatas standar yang telah ditentukan. Semakin tinggi BOPO semakin tidak efisien bank tersebut dalam mengendalikan biaya operasionalnya, dengan tidak efisiensinya biaya maka keuntungan yang diperoleh bank akan semakin kecil.

4. Tahun 2016

BOPO $=\frac{R p \cdot 4.921 .551}{R p \cdot 4.431 .618} \times 100=111 \%$

Artinya, menurut standar BI BOPO di bawah $90 \%$ bank dapat dikatakan efisien dalam menjalankan kegiatan operasionalnya, sementara kemampuan BPR LPN Tarantang dalam melakukan kegiatan operasionalnya dengan nilai BOPO sebesar $111 \%$ diatas standar yang telah ditentukan.

d. Net Profit Margin (NPM)

Merupakan rasio yang menghitung sejauh mana kemampuan perusahaan menghasilkan laba bersih pada tingkat penjualan tertentu. Menurut standar BI NPM lebih dari 5\% dapat dikatakan bagus. Berdasarkan data yang diperoleh NPM BPR LPN Tarantang dari tahun 2013 sampai dengan tahun 2016 ditunjukkan pada tabel dibawah ini. 
Tabel 5

Perhitungan Net Profit Margin BPR LPN Tarantang Kabupaten Dharmasraya Tahun 2013-2016 (Dalam Ribuan Rupiah)

\begin{tabular}{|l|r|r|r|r|}
\hline \multicolumn{1}{|c|}{ Komponen } & \multicolumn{1}{c|}{2013} & \multicolumn{1}{c|}{2014} & \multicolumn{1}{c|}{2015} & \multicolumn{1}{c|}{2016} \\
\hline a.Laba bersih setelah pajak & 687.449 & 219.273 & 714.753 & 445.285 \\
\hline b.Pend. Operasional & & & & \\
\hline -Bunga & 5.069 .016 & 4.921 .367 & 4.081 .907 & 3.243 .896 \\
\hline -Provisi & 306.938 & 370.192 & 9.026 & 172.546 \\
\hline -Lainnya & 308.614 & 272.102 & 218.138 & .015 .176 \\
\hline Jumlah pend. Operasional & 5.684 .568 & 5.563 .661 & 4.081 .071 & 4.431 .618 \\
\hline Net Profit Margin & $12,09 \%$ & $03,94 \% \%$ & $16,28 \%$ & $10,04 \%$ \\
\hline
\end{tabular}

Sumber : Data Olahan

Dengan Formula :

1. Tahun 2013

$$
\mathrm{NPM}=\frac{\text { Laba bersih setelah pajak }}{\text { Total Pendapatan Operasional }} \times 100 \%
$$

$\mathrm{NPM}=\frac{R p .687 .449}{R p .5 .684 .568} \times 100 \%=12,09 \%$

Artinya kemampuan BPR LPN Tarantang dalam menghasilkan laba bersih jika dilihat dari NPM yang dimiliki bank ini sebesar 12,09\% artinya bahwa setiap Rp. 1 nilai penjualan, akan menghasilkan Rp. 0,12 laba setelah pajak. Menurut standar BI NPM dapat dikatakan bagus jika lebih dari 5\%, sementara BPR LPN Tarantang mampu menghasilkan NPM sebesar 12,09\% melebihi dari standar yang telah ditentukan. Semakin tinggi nilai NPM, semakin besar laba bersih yang diperoleh bank pada tingkat penjualan tertentu.

2. Tahun 2014

$\mathrm{NPM}=\frac{R p \cdot 219 \cdot 273}{R p \cdot 5 \cdot 563 \cdot 661} \times 100=03,94 \%$

Artinya kemampuan BPR LPN Tarantang dalam menghasilkan laba bersih jika dilihat dari NPM yang dimiliki bank ini sebesar 03,94\% artinya bahwa setiap Rp. 1 nilai penjualan, akan menghasilkan Rp. 0,03 laba setelah pajak. Menurut standar BI NPM dapat dikatakan bagus jika lebih dari 5\%, sementara BPR LPN Tarantang mampu menghasilkan NPM sebesar 03,94\% dibawah standar yang telah ditentukan, karena kecilnya kemampuan bank dalam menghasilkan Net Profit Margin.

3. Tahun 2015

$\mathrm{NPM}=\frac{R p \cdot 714 \cdot 753}{R p \cdot 4 \cdot 389 \cdot 071} \times 100=16,28 \%$

Artinya kemampuan BPR LPN Tarantang dalam menghasilkan laba bersih jika dilihat dari NPM yang dimiliki bank ini sebesar 16,28\% artinya bahwa setiap Rp. 1 nilai penjualan, akan menghasilkan Rp. 0,16 laba setelah pajak. Menurut standar Bank Indonesia NPM dapat dikatakan bagus jika lebih dari 5\%, sementara BPR LPN Tarantang mampu menghasilkan NPM sebesar 16,28\% melebihi dari standar yang telah ditentukan. 
4. Tahun 2016

$\mathrm{NPM}=\frac{R p \cdot 445 \cdot 285}{R p \cdot 4 \cdot 431 \cdot 618} \times 100=10,04 \%$

Artinya kemampuan BPR LPN Tarantang dalam menghasilkan laba bersih jika dilihat dari NPM yang dimiliki bank ini sebesar 10,04\% artinya bahwa setiap Rp. 1 nilai penjualan, akan menghasilkan Rp. 0,10 laba setelah pajak. Menurut standar Bank Indonesia NPM dapat dikatakan bagus jika lebih dari 5\%, sementara BPR LPN Tarantang mampu menghasilkan NPM sebesar 10,04\% melebihi dari standar yang telah ditentukan.

\section{SIMPULAN}

Berdasarkan analisis laporan keuangan dengan menggunakan rasio profitabilitas dalam menilai kemampuan perusahaan memperoleh laba pada laporan keuangan PT. BPR LPN Tarantang tahun 2013 sampai dengan tahun 2016, dapat ditarik kesimpulan sebagai berikut :

1. Dari rasio ROA BPR LPN Tarantang pada tahun 2013 nilai ROA 2,43\%, tahun 2014 nilai ROA 08,60\%, tahun 2015 nilai ROA 3,10\%, tahun 2016 nilai ROA 1,69\%, kemampuan bank dalam menghasilkan laba bersih sebelum pajak terhadap penggunaan sejumlah aktiva yang dimiliki bank untuk tahun 2013, 2015, 2016 sudah dapat dikatakan baik karena di atas standar yang telah ditentukan oleh BI yaitu sebesar 1,5\%, untuk tahun 2014 08,60\% di bawah standar yang telah ditentukan.

2. Dari rasio ROE BPR LPN Tarantang tahun 2013 nilai ROE 17,18\%, tahun 2014 nilai ROE 5,48\%, sedangkan tahun 2015 nilai ROE 17,86\%, dan tahun 2016 nilai ROE 11,13\%. Kemampuan bank dalam menghasilkan laba bersih setelah pajak terhadap penggunaan modal sendiri untuk tahun 2013 dan tahun 2015 dikatakan baik karena di atas standar BI yaitu 12\%, untuk rasio NPM tahun 2014 dan tahun 2016 di bawah standar yang telah ditentukan kecilnya kemampuan bank dalam menghasilkan NPM.

3. Dari rasio BOPO tahun 2013 nilai BOPO 88,04\%, tahun 2014 nilainya $96,27 \%$, tahun 2015 nilai BOPO 116\% sedangkan tahun 2016 nilainya $111 \%$, menurut standar BI jika rasio BOPO melebihi $90 \%$ maka bank dikategorikan tidak efisien dalam menjalankan kegiatan operasionalnya, sementara rasio BOPO BPR LPN Tarantang dari tahun 2013 sampai dengan tahun 2016 meningkat secara berturut-turut di atas $90 \%$ dari standar yang ditentukan, maka bank ini dikategorikan tidak efisien dalam menjalankan kegiatan operasionalnya.

4. Dari rasio NPM BPR LPN Tarantang tahun 2013 nilainya 12,09\%, tahun 2014 nilainya $03,94 \%$, tahun 2015 nilainya 16,28\%, sedangkan tahun 2016 nilainya 10,04\%. Nilai rasio NPM BPR LPN Tarantang dari tahun 2013 sampai dengan tahun 2016 pada tingkat penjualan tertentu dikatakan bagus karena diatas standar BI yaitu lebih dari 5\%, walaupun tahun 2014 nilai rasio NPM di bawah standar yang telah ditentukan namun tahun berikutnya mengalami peningkatan. 


\section{DAFTAR PUSTAKA}

Afriyeni, A. Fernos, J (2018). Analisis Faktor-Faktor Penentu Kinerja Profitabilitas Bank Perkreditan Rakyat (BPR) Konvensional Di Sumatera Barat. Jurnal Benefita: Ekonomi Pembangunan Manajemen Bisnis Dan Akuntansi. Volume 3. No. 3. http://doi.org/10.22216/jbe.v3i3.3623

Abdullah, Tantri. Dkk. 2012. Bank dan Lembaga Keuangan. Jakarta : PT. Raja Grafindo Persada.

Arifin, I. Z., \& Marlius, D. (2017). Analisis Kinerja Keuangan PT. Pegadaian Cabang Ulak Karang. https://doi.org/10.31227/osf.io/n2peu

Dendawijaya, Lukman. 2001. Manajemen Perbankan. Jakarta : Ghalia Indonesia.

Fernos, J (2017). Analisis Rasio Profitabilitas Untuk Mengukur Kinerja (Studi Kasus Pada PT. Bank Pembangunan Daerah Provinsi Sumatera Barat. Jurnal Pundi. Vol 01. No 02. https://doi.org/10.31575/jp.v1i2.25

Handayani, M., \& Marlius, D. (2017). Analisis Tingkat Kesehatan PT. BPR Batang Kapas. https://doi.org/10.31227/osf.io/bq48z

Harahap, 2009. Analisis Laporan Keuangan. Edisi ke-1, Jakarta : PT. Raja Grafindo Persada.

Harahap, Sofyan Syafri. 1997. Analisis Kritis Atas Laporan Keuangan. Jakarta : PT. Raja Grafindo Persada.

Iswari, M., \& Fernos, J. (2019). Analisis Tingkat Kesehatan Bank Pada PT. Bank Pembangunan Daerah Sumatera Barat. https://doi.org/10.31227/osf.io/ja7ty

Kasmir, 2008. Analisis Laporan Keuangan. Jakarta : PT. Raja Grafindo Persada. Latif, F., \& Fernos, J. (2019). Analisis Rasio Profitabilitas Untuk Mengukur Kinerja Bank BPR Harau Payakumbuh. https://doi.org/10.31227/osf.io/27vqg

Muljono, Teguh Pudjo. 1995. Analisa Laporan Keuangan Untuk Perbankan. Edisi revisi. Jakarta : Djambatan.

Munawir, 2002. Analisis Laporan Keuangan. Yogyakarta : Liberty.

Putri, Y. A., \& Marlius, D. (2018). Analisis Tingkat Kesehatan Bank Pada PT. Bank Perkreditan Rakyat (BPR) Jorong Kampuang Tangah Pariaman Cabang Padang. https://doi.org/10.31227/osf.io/r98pv 
Rahmayeli, D. S., \& Marlius, D. (2017). Analisis Kinerja Keuangan Pada PT. Bank Perkreditan Rakyat (BPR) Batang Kapas Pesisir Selatan. https://doi.org/10.31227/osf.io/sz5db

Undang-Undang Republik Indonesia No. 10 tahun 1998, Tentang Perubahan Undang-Undang No. 7 Tahun 1992 Tentang perbankan.

http//www.laporan keuangan.com 